\title{
Review
}

\section{Pathologic patterns of interleukin 10 expression - A review}

\author{
Jasenka Trifunovićc ${ }^{*}$, Larisa Miller² ${ }^{2}$ Željko Debeljak ${ }^{3}$, Vesna Horvat ${ }^{3}$ \\ 'Department of Medical Biochemistry, Special Hospital for Medical Rehabilitation Varaždinske Toplice, Varaždinske Toplice, Croatia \\ ${ }^{2}$ Center of Excellence Medical Publications, EMD Serono Research and Development Institute, Billerica, United States of America \\ ${ }^{3}$ Department of Clinical Laboratory Diagnostics, Clinical Hospital Centre Osijek, Osijek, Croatia
}

*Corresponding author: jasenka.trifunovic@yahoo.com

\begin{abstract}
Interleukin 10 (IL-10) is important pleiotropic immunoregulatory cytokine which gene is located on chromosome 1 at 1q31-32. There are many genetic variants of IL-10 gene. However, the most studied are two dinucleotide repeats (microsatellites), IL10.G and IL10.R, located 1.2 kb and $4 \mathrm{~kb}$ upstream of the transcription start site and three single nucleotide polymorphisms (SNPs) $-1082(\mathrm{G} / \mathrm{A}),-819(\mathrm{C} / \mathrm{T})$ and $-592(\mathrm{C} / \mathrm{A})$. A large number of studies have shown that IL-10 gene polymorphisms are associated with different diseases and play an important role in pathophysiology and clinical course of these diseases. This review summarizes published literature knowledge about the association of IL-10 polymorphisms and expression patterns with asthma, systemic lupus erythematosus, psoriasis, inflammatory bowel disease, rheumatoid arthritis, tuberculosis and some neoplasms.
\end{abstract}

Key words: autoimmune diseases; inflammatory diseases; interleukin 10; neoplasms; polymorphisms, genetic

\section{Introduction}

Cytokines play an important role in modulation of the immune response. They are produced by immune cells upon stimulation. By binding to specific receptors cytokines can either up-regulate activation, proliferation and differentiation of target cells, mediate or regulate immune reactions, inhibit the growth of cells, act cytotoxic, induce or inhibit the production of other cytokines. Cytokines are divided in two groups according to the function: anti-inflammatory and pro-inflammatory cytokines. Lack of balance between pro- and anti-inflammatory cytokines disables proper function of immune system. In recent years, many researchers have noticed that differences in cytokine levels (high or low) are associated with certain allelic variants of cytokine genes. These polymorphisms might play an important role in the pathophysiology of various diseases.

Interleukin 10 (IL-10) is an important pleiotropic immunoregulatory cytokine mainly secreted by macrophages, but also by Thelper 1 (Th1) and Th2 lymphocytes, dendritic cells, cytotoxic T cells, B lymphocytes, monocytes and mast cells. Some studies have shown that it can be produced even by human carcinoma cell lines $(1,2)$. IL-10 activity is mediated by the IL-10 receptor (IL-10R) which is a member of the class II cytokine receptor family. IL10 inhibits the capacity of monocytes and macrophages to present antigen to T cells via an inhibitory effect on expression of major histocompatibility complex (MHC) class II, costimulatory molecules such as CD80 (B7.1) and CD86 (B7.2) and therefore downregulates the expression of IL-1, IL6, IL-8, IL-12 and tumor necrosis factor - alpha (TNF-a). In B cells, IL-10 prevents apoptosis, enhances cell proliferation and has a role in immunoglobulin (lg) class switch.

The IL-10 gene is located on chromosome 1 at 1q31-32, spans about $4.7 \mathrm{~kb}$ and contains four introns and five exons (3). There are many genetic variants of IL-10 gene. However, the most studied are two dinucleotide repeats (microsatellites), 
IL10.G and IL10.R, located $1.2 \mathrm{~kb}$ and $4 \mathrm{~kb}$ upstream of the transcription start site $(4,5)$ and three single nucleotide polymorphisms (SNPs) -1082(G/A), $-819(C / T)$ and $-592(C / A)(6)$ which form three predominant haplotypes (GCC, ACC, ATA). Although endogenous and exogenous factors stimulate cells to produce IL-10, its secretion also depends on IL10.R, IL10.G and SNP polymorphisms in promoter region. A summary of all IL-10 polymorphisms and haplotypes associated with diseases and their links to expression patterns are shown in Table 1.

The pleiotropic role of IL-10 in immune system regulation coupled with polymorphic regulation of its expression, presents additional challenges for interpretation, especially in the context of disease pathophysiology. The aim of this review was to present the most studied associations of IL-10 polymorphisms with susceptibility to selected diseas- es and their severity. A literature search was conducted using PubMed and SCOPUS from January 2000 through to April 2014. Additional literature references were found by reviewing reference lists. Search was first performed using the search term "Interleukin 10 polymorphism" to discover which IL-10 polymorphisms and diseases were studied the most. Those were three single nucleotide polymorphisms (SNPs): 1082(G/A), $-819(\mathrm{C} / \mathrm{T})$ and $-592(C / A)$ in the promoter region which form three predominant haplotypes (GCC, ACC, ATA). The most studied diseases were asthma, systemic lupus erythematosus, psoriasis, inflammatory bowel disease, rheumatoid arthritis, tuberculosis and neoplasms. Further search was referred only to these diseases. Inclusion criteria for the review were publications limited to humans, well design case-control studies (sample size $>100$, well-defined group of cases and controls, detailed meth-

TABLE 1. Summary of IL-10 polymorphisms associated with diseases and their links to expression patterns.

\begin{tabular}{|c|c|c|c|c|c|c|}
\hline \multirow[b]{2}{*}{$\begin{array}{l}\text { Polymorphism / } \\
\text { haplotype }\end{array}$} & \multirow[b]{2}{*}{ Disease } & \multicolumn{3}{|c|}{ IL-10 } & \multirow[b]{2}{*}{$\begin{array}{c}\text { Number of } \\
\text { cases / } \\
\text { number } \\
\text { of controls }\end{array}$} & \multirow[b]{2}{*}{ Reference } \\
\hline & & $\begin{array}{l}\text { Level of } \\
\text { IL-10 in cases } \\
\text { compared to } \\
\text { controls }\end{array}$ & $\begin{array}{c}\text { Sample } \\
\text { type }\end{array}$ & $\begin{array}{l}\text { IL-10 } \\
\text { expression }\end{array}$ & & \\
\hline \multirow{2}{*}{$\begin{array}{l}\text { ATA at position } \\
-1082,-819,-592\end{array}$} & asthma & NM & / & / & $272 / 307$ & Chatterjee et al. (10); 2005. \\
\hline & psoriasis & NM & / & / & $248 / 148$ & Kingo et al. (30); 2003. \\
\hline \multirow{11}{*}{$-1082 G$} & asthma & NM & / & / & $2215 / 2170$ & Hyun et al. (13); 2013. \\
\hline & \multirow{4}{*}{$\begin{array}{l}\text { systemic lupus } \\
\text { erythematosus }\end{array}$} & NM & / & / & $7948 / 11866$ & Liu et al. (24); 2013. \\
\hline & & NM & / & / & $2828 / 4008$ & Song et al. (25); 2013. \\
\hline & & NM & / & / & $2396 / 3653$ & Zhou et al. (26); 2013. \\
\hline & & NM & / & / & $2399 / 3483$ & Nath et al. (27); 2005. \\
\hline & Crohn's disease & NM & / & / & $228 / 572$ & Fernandez et al. (32); 2005. \\
\hline & $\begin{array}{l}\text { non-small cell lung } \\
\text { cancer }\end{array}$ & NM & / & / & $154 / 205$ & Shih et al. (65); 2005. \\
\hline & \multirow{2}{*}{$\begin{array}{l}\text { diffuse large B-cell } \\
\text { lymphoma }\end{array}$} & NM & / & / & $199 / 112$ & Lech-Maranda et al. (66); 2004. \\
\hline & & NM & / & / & $1073 / 1738$ & Cao et al. (67); 2013. \\
\hline & cervical cancer & NM & / & / & $267 / 173$ & Matsumoto et al. (68); 2010. \\
\hline & oral cancer & NM & / & / & 144 / 141 & Vairaktaris et al. (69); 2008. \\
\hline \multirow{4}{*}{$-1082 A A$} & $\begin{array}{l}\text { rheumatoid } \\
\text { arthritis }\end{array}$ & NM & / & / & $162 / 373$ & de Paz et al. (42); 2010. \\
\hline & \multirow{2}{*}{ asthma } & NM & / & / & 4716 / 5093 & Zheng et al. (11); 2014. \\
\hline & & NM & / & / & 4478 / 4803 & Nie et al. (12); 2012. \\
\hline & tuberculosis & NM & / & / & $5319 / 6723$ & Zhang et al. (54); 2011. \\
\hline
\end{tabular}




\begin{tabular}{|c|c|c|c|c|c|c|}
\hline \multirow[b]{2}{*}{$\begin{array}{l}\text { Polymorphism / } \\
\text { haplotype }\end{array}$} & \multirow[b]{2}{*}{ Disease } & \multicolumn{3}{|c|}{ IL-10 } & \multirow[b]{2}{*}{$\begin{array}{c}\text { Number of } \\
\text { cases / } \\
\text { number } \\
\text { of controls }\end{array}$} & \multirow[b]{2}{*}{ Reference } \\
\hline & & $\begin{array}{l}\text { Level of } \\
\text { IL-10 in cases } \\
\text { compared to } \\
\text { controls }\end{array}$ & $\begin{array}{l}\text { Sample } \\
\text { type }\end{array}$ & $\begin{array}{l}\text { IL-10 } \\
\text { expression }\end{array}$ & & \\
\hline \multirow{5}{*}{$-1082 G G$} & \multirow{2}{*}{ Crohn's disease } & NM & l & / & 3693 / 4574 & Lv et al. (34); 2014. \\
\hline & & NM & / & / & 7704 / 9881 & Zhu et al. (33); 2013. \\
\hline & \multirow{2}{*}{ tuberculosis } & $\uparrow$ & blood & protein & $178 / 188$ & Ansari et al. (55); 2009. \\
\hline & & NM & / & / & $300 / 100$ & Meenakshi et al. (56); 2013. \\
\hline & $\begin{array}{l}\text { rheumatoid } \\
\text { arthritis }\end{array}$ & NM & l & l & $244 / 106$ & $\begin{array}{l}\text { Paradowska-Gorycka et al. (43); } \\
2010 .\end{array}$ \\
\hline$-1082 \mathrm{GA}$ & Crohn`s disease & NM & l & l & 7704 / 9881 & Zhu et al. (33); 2013. \\
\hline \multirow{6}{*}{$-592 A A$} & \multirow{2}{*}{ asthma } & NM & I & / & $4716 / 5093$ & Zheng et al. (11); 2014. \\
\hline & & NM & / & / & 4478 / 4803 & Nie et al. (12); 2012. \\
\hline & \multirow{2}{*}{$\begin{array}{l}\text { rheumatoid } \\
\text { arthritis }\end{array}$} & NM & / & / & $244 / 106$ & $\begin{array}{l}\text { Paradowska-Gorycka et al. (43); } \\
2010 .\end{array}$ \\
\hline & & $\downarrow$ & blood & protein & $164 / 196$ & Ying et al. (46); 2011. \\
\hline & prostate cancer & NM & / & / & $509 / 382$ & Faupel-Badger et al. (71); 2008. \\
\hline & colon cancer & $\downarrow$ & tissue & mRNA & $160 / 160$ & Cacev et al. (72); 2008. \\
\hline \multirow{3}{*}{$-592 A$} & \multirow{2}{*}{$\begin{array}{l}\text { rheumatoid } \\
\text { arthritis }\end{array}$} & NM & / & l & $244 / 106$ & $\begin{array}{l}\text { Paradowska-Gorycka et al. (43); } \\
2010 .\end{array}$ \\
\hline & & $\downarrow$ & blood & protein & $164 / 196$ & Ying et al. (46); 2011. \\
\hline & $\begin{array}{l}\text { diffuse large B-cell } \\
\text { lymphoma }\end{array}$ & NM & / & / & $199 / 112$ & Lech-Maranda et al. (66); 2004. \\
\hline$-592 C$ & $\begin{array}{l}\text { non-small cell lung } \\
\text { cancer }\end{array}$ & NM & / & / & $154 / 205$ & Shih et al. (65); 2005. \\
\hline$-592 C C$ & tuberculosis & NM & / & l & $6559 / 7768$ & Liang et al. (57); 2014. \\
\hline \multirow{4}{*}{$-819 C$} & $\begin{array}{l}\text { systemic lupus } \\
\text { erythematosus }\end{array}$ & NM & / & / & $2828 / 4008$ & Song et al. (25); 2013. \\
\hline & $\begin{array}{l}\text { inflammatory } \\
\text { bowel disease }\end{array}$ & NM & l & / & 3693 / 4574 & Lv et al. (34); 2014. \\
\hline & tuberculosis & NM & / & / & $6559 / 7768$ & Liang et al. (57); 2014. \\
\hline & $\begin{array}{l}\text { non-small cell lung } \\
\text { cancer }\end{array}$ & NM & / & / & $154 / 205$ & Shih et al. (65); 2005. \\
\hline$-819 \mathrm{~T}$ & $\begin{array}{c}\text { diffuse large B-cell } \\
\text { lymphoma }\end{array}$ & NM & / & / & $199 / 112$ & Lech-Maranda et al. (66); 2004. \\
\hline \multirow{2}{*}{-819TT } & colon cancer & $\downarrow$ & tissue & mRNA & $160 / 160$ & Cacev et al. (72); 2008. \\
\hline & prostate cancer & NM & / & / & $509 / 382$ & Faupel-Badger et al. (71); 2008. \\
\hline
\end{tabular}

${ }^{*} \mathrm{NM}$ - IL-10 concentration was not measured

$\uparrow$ - increased level of IL-10 in cases compared to controls.

$\downarrow$ - decreased level of IL-10 in cases compared to controls.

ods, $\mathrm{P}<0.05$ ), meta-analysis (with stratification by age or ethnic origin if possible). No age limits were set. Power analysis has not been performed in any of the studies included in this review. All data are presented systematically and summarized in ta- bles sorted according to the type of illness (IL-10 polymorphism / haplotype associated with the disease, frequency of polymorphism / haplotype in cases compared to controls, population represented in the study). 


\section{IL-10 in autoimmune and inflammatory diseases}

\section{Asthma}

Asthma is a complex disorder in which both genetic and environmental risk factors play an important role in pathogenesis of the disease. Proinflammatory cytokines produced by Th2 cells have an important role in the chronic inflammation in asthma since they are responsible for $\lg \mathrm{E}$ dysregulation (IL-4, IL-13), eosinophilia (IL-5, granulocyte-macrophage-colony stimulating factor (GM-CSF), IL-3), mast cell proliferation (IL-3, IL-9), IgE class switching (IL-4, IL-13) and hypersecretion of mucus and regulation of airway hypersensitivity (IL-13). Therefore, asthma is considered to be a Th2 disease (7). The intrinsic physiologic mechanism for inhibiting pro-inflammatory cytokine synthesis is cytokine IL-10 (8). In healthy lungs the main sources of IL-10 are alveolar macrophages and circulating monocytes (9). In bronchoalveolar lavage (BAL) alveolar macrophages represent more than $80 \%$ of the cells present, while Th1 and Th2 lymphocytes, cytotoxic $T$ cells, B lymphocytes and mast cells represent less than $10 \%$ of the cells (8).

An inverse association between severity of asthma and IL-10 concentration was shown by Borish et al. (8) who measured concentration of IL-10 in BAL in normal and asthmatic subjects using IL-10 enzyme-linked immunosorbent assay (ELISA). In BAL fluid of asthmatic patients IL-10 concentration was lower than in healthy controls $(P<0.01)$. Absence of IL-10 in asthma causes the continued secretion of pro-inflammatory cytokines such as IL-6, IL-5, IL4, TNF- $a$, GM-CSF and IL-1 which contribute to asthmatic airway inflammation.

Many candidate genes and SNPs have been studied and found out to be associated with asthma (Table 2). Chattarjee et al. (10), using both casecontrol and family studies, showed that haplotype ATA at position $-1082,-819,-592$ was present more in asthmatics $(\mathrm{N}=272)$ than in controls $(\mathrm{N}=307)(\mathrm{P}$ $=0.009$ ) while haplotype ATC at position -1082 , $-819,-592$ was more present in controls than in asthmatics $(P=0.012)$ in North Indians. IL-10 metaanalysis involving 4716 asthmatic patients and 5093 controls showed the association of -1082AA, -592AC and -592AA genotypes with asthma susceptibility in Asian adults (11). This association was also shown in meta-analysis involving 4478 asthmatic patients and 4803 controls from different populations (12). Eleven studies involving 2215 asthma patients and 2170 controls were included in a meta-analysis performed by Hyun et al. (13). Stratification by ethnicity indicated an association between the IL-10 -1082G allele and asthma in East Asians $(P=0.02)$. Stratification by age indicated an association between the IL-10 $-1082 \mathrm{G}$ allele and asthma in adults $(P=0.02)$.

\section{Systemic lupus erythematosus}

Systemic lupus erythematosus (SLE) is a complex autoimmune disease characterized by $B$ lymphocyte hyperactivity and production of autoantibod-

TABLE 2. Association of IL-10 polymorphism and haplotype with asthma.

\begin{tabular}{cccc}
\hline Polymorphism & $\begin{array}{c}\text { Frequency of } \\
\text { polymorphism / haplotype } \\
\text { in cases compared to } \\
\text { controls }\end{array}$ & Population & Reference \\
\hline -1082AA & $\uparrow$ & meta-analysis & Zheng et al. (11); 2014. Nie et al. (12); 2012. \\
-1082G & $\downarrow$ & East Asians & Hyun et al. (13); 2013. \\
-592AA & $\uparrow$ & meta-analysis & Zheng et al. (11); 2014. Nie et al. (12); 2012. \\
-592AC & $\uparrow$ & meta-analysis & Zheng et al. (11); 2014. Nie et al. (12); 2012. \\
ATA at position -1082, \\
$-819,-592$
\end{tabular}

\footnotetext{
$\uparrow$ - increased frequency of polymorphism / haplotype in cases compared to controls.
}

$\downarrow$ - decreased frequency of polymorphism / haplotype in cases compared to controls. 
ies directed against double-stranded DNA, dysfunction of antigen-presenting cells (APC) and T lymphocytes. Increased production and decreased clearance of immune complexes leads to immune complex deposition in tissue and damage to multiple organ systems. IL-10 has the ability to induce autoantibody production by B lymphocytes suggesting that IL-10 plays an important role in the pathogenesis of SLE (14).

The major sources of IL-10 in patients with SLE are $B$ cells and monocytes. IL-10 overproduction by $B$ lymphocytes and monocytes was described for the first time by Llorente et al. (15). This observation was also confirmed by several other studies $(16,17)$. Abnormal production of autoantibodies by B lymphocytes in patients with SLE is IL-10 dependent and all related studies demonstrated that there is a positive correlation of serum IL-10 levels with disease activity (18-20). Interferons that are produced early in disease, as part of the immune response, have capacity to change IL-10 function from anti- to pro-inflammatory, so in this context IL-10 contributes to inflammation (21). In addition, immune complexes, that are produced in SLE, acting through Fc gamma receptor II (FcgRII) stimulate IL-10 production from peripheral blood mononuclear cells (PBMC), thus perpetuating the pathological cycle. Rönnelid et al. (22) showed a significant increase in IL-10 production in cell cultures incubated with SLE sera, in comparison to cell cultures incubated with control sera. This effect provides a possible explanation for the enhanced production of IL-10 in patients with SLE, which leads to B cell hyperactivity, autoantibody production, immune complexes production, PBMC stimulation and again production of IL-10. Creation of this cy- cle leads to increased deposition of immune complexes in tissues and SLE associated pathology.

Numerous studies have investigated the association between the $-1082(\mathrm{G} / \mathrm{A}),-819(\mathrm{C} / \mathrm{T})$ and $-592(\mathrm{C} /$ A) polymorphisms and susceptibility to SLE, but the results were inconsistent. Therefore, a large number of meta-analysis in the last few years have been performed to assess the association between SLE and the IL-10 polymorphisms (Table 3). Twelve studies including 1765 cases and 2444 controls were included in a meta-analysis performed by Wang et al. (23). The results indicated that there is a lack of association between the haplotype GCC at position -1082, $-819,-592$ and SLE risk, but another meta-analysis that included 7948 cases and 11866 controls has shown that the haplotype GCC at position $-1082,-819,-592$ is associated with SLE susceptibility same as $-1082 \mathrm{G}$ allele (24). In meta-analysis involving 2828 SLE patients and 4008 controls (25), stratification by ethnicity indicated an association between the GCC haplotype and SLE in Europeans, IL-10 -819C allele and SLE in Asians, while an association between the IL-10 $-1082 \mathrm{G}$ allele and SLE in Europeans was also indicated in meta-analysis (2396 cases and 3653 controls) performed by Zhou et al. (26). Meta-analysis that included 2399 SLE patients and 3483 controls showed that $-1082 \mathrm{G}$ allele is associated with SLE in Asians (27).

\section{Psoriasis}

Psoriasis is a cutaneous disorder characterized by overexpression of pro-inflammatory Th1 cytokines (IL-2, interferon-gamma (IFN- $\gamma$ ), TNF-a) while the level of expression of anti-inflammatory cytokines

TABLE 3. Association of IL-10 polymorphism with systemic lupus erythematosus.

\begin{tabular}{cccc}
\hline Polymorphism & $\begin{array}{c}\text { Frequency of } \\
\text { polymorphism in cases } \\
\text { compared to controls }\end{array}$ & Population & Reference \\
\hline -1082G & $\uparrow$ & meta-analysis & Liu et al. (24); 2013. \\
& & European et al. (25); 2013. & Zhou et al. (26); 2013. \\
$-\mathbf{- 8 1 9 C}$ & $\uparrow$ & European & Nath et al. (27); 2005. \\
\hline
\end{tabular}

$\uparrow$ - increased frequency of polymorphism / haplotype in cases compared to controls. 
(IL-4, IL-10) is low and insufficient to counterbalance pro-inflammatory effects. Low levels of IL-10 were observed in many studies $(28,29)$ and it is believed that it plays a key role in the pathology and in the clinical course of psoriasis.

Polymorphisms of IL-10 promoter region in psoriasis were frequently investigated. In a study that involved 248 patients with plaque type of psoriasis and 148 controls it was shown that ATA haplotype has a role in determining severity and course of plaque type of psoriasis since it is associated with persistent eruption $(P<0.01)(30)$. A meta-analysis involving Asian psoriasis patients $(\mathrm{N}=1018)$ and controls $(N=1186)$ found significant association between psoriasis and the IL-10 -1082G allele ( $\mathrm{P}=$ 0.011) (31).

\section{Inflammatory bowel disease}

Inflammatory bowel disease (IBD), which includes Crohn's disease (CD) and ulcerative colitis (UC), is a chronic relapsing disease characterized by inflammation of gastrointestinal tract, which leads to destruction of the mucosa. An important element in pathogenesis of IBD is disregulation of the intestinal immune system. In the normal intestinal immune system the balance of pro- and anti-inflammatory cytokines is essential for gut homeostasis. However, in IBD peripheral blood monocytes, intestinal monocytes and polymorphonuclear neutrophil granulocytes produce high amounts of pro-inflammatory cytokines (IL-6, TNF- $\alpha$, IL-1 $\beta$, IL-8) which leads to differentiation or proliferation of a variety of cells and tissue damage.
Genetic factors were also found to be associated with the development of UC and CD (Table 4). Frequencies of IL10.G14 microsatellite allele and IL-10 $-1082 \mathrm{G}$ allele were higher in patients with $\mathrm{CD}(\mathrm{N}=$ 228) compared to patients with UC $(N=242)$ and controls ( $\mathrm{N}=572)$ (32). Zhu et al. (33) performed meta-analysis (7704 IBD patients and 9881 controls) to estimate the association between -1082A/ $G$ polymorphism in the IL-10 gene and IBD susceptibility. The results demonstrated association between heterozygote genotypes -1082GA and -1082 GG and CD. Another meta-analysis (3693 cases and 4574 controls) showed association of -1082 GG genotype and CD and -819 C and IBD (34).

\section{Rheumatoid arthritis}

Rheumatoid arthritis (RA) is a chronic inflammatory autoimmune disease that is characterized with chronic synovitis, which often leads to joint destruction. Expression of pro- and anti-inflammatory cytokines in the synovial membrane of the in flamed joint is altered. Pro-inflammatory cytokines, TNF- $a$ and IL-1, are overproduced by macrophages, synovial fibroblasts and neutrophils and play an important role in the process of chronic inflammation and joint destruction.

Synovial fluid from patients with RA also contains detectable levels of anti-inflammatory cytokine IL10 but they are insufficient to counterbalance the effect of pro-inflammatory cytokines (35). The cellular sources of IL-10 in the synovial tissue are macrophages and T cells (35). In the presence of TNF-a and IL-1 expression of IL-10R on surface of dendritic cells in synovial fluid is low (36). Also, chronic ex-

TABLE 4. Association of IL-10 polymorphism with inflammatory bowel disease.

\begin{tabular}{ccccc}
\hline Polymorphism & $\begin{array}{c}\text { Frequency of } \\
\text { polymorphism in cases } \\
\text { compared to controls }\end{array}$ & Disease & Population & Reference \\
\hline IL10.G14 & $\uparrow$ & Crohn's disease & Spanish & Fernandez et al. (32); 2005. \\
-1082G & $\uparrow$ & Crohn's disease & Spanish & Fernandez et al. (32); 2005. \\
-1082GA & $\uparrow$ & Crohn's disease & Meta-analysis & Zhu et al. (33); 2013. \\
-1082GG & $\uparrow$ & Crohn's disease & Meta-analysis & Lv et al. (34); 2014. \\
-819C & $\uparrow$ & Crohn's disease, ulcerative colitis & Meta-analysis & Lh et al. (34); 2014. \\
\hline
\end{tabular}

$\uparrow$ - increased frequency of polymorphism / haplotype in cases compared to controls. 
posure of the pro-inflammatory cytokines (TNF-a and IL-1) modulates the IL-10 signalling and bioactivity in synovial macrophages during chronic inflammation (37). RA patients showed significantly reduced IL-10 levels in serum in comparison to healthy donors, suggesting that IL-10 synthesis is depressed in RA (38). In addition, patients with advanced RA had the lowest values of IL-10 in serum (39). On the contrary, some studies have shown that concentration of IL-10 in sera of patients with RA is higher as compared to controls $(40,41)$. Polymorphisms within the IL-10 gene promoter are associated with RA (Table 5). Frequency of genotype -1082AA was lower $(P=0.006)$ in RA patients $(N=$ 162) when compared to the control group ( $\mathrm{N}=$ 373) (42). In study performed by Paradowska-Gorycka et al. (43) it was found that frequency of genotype -1082GG was lower $(P=0.0001)$ while frequency of genotype $-1082 \mathrm{GA}$ was higher $(\mathrm{P}=$ $0.009)$ in RA patients $(\mathrm{N}=244)$ comparing to the control group ( $\mathrm{N}=106)$. A total of 1480 cases and 1413 controls in 10 case-control studies were included in meta-analysis performed by Zhang et al. (44). The results indicated that people with IL-10 -1082GG and -1082GA genotype had a 25\% lower risk of RA, when compared with the people with IL-10 -1082AA genotype. Meta-analysis (2647 RA patients and 3383 controls) showed association of the IL-10 -592C allele and the IL-10 -592CC genotype with RA (45). In Polish (43) and Chinese (46)
RA patients frequency of -592AA genotype was significantly higher compared to controls, same as frequency of genotype -592CA and allele -592A, suggesting that allele $A$ is associated with the lower expression of the IL-10 protein.

\section{Tuberculosis}

Tuberculosis (TBC) is caused by Mycobacterium tuberculosis, an intracellular pathogen, which primarily enters the human organism through respiratory tract and is phagocytised by macrophages and dendritic cells. Phagocytic cells undergo activation and maturation, which increases their potential to stimulate $T$ cells. Cytokines released by activated $T$ cells regulate differentiation, proliferation and effector functions of phagocytic cells with a purpose of removing intracellular pathogen and limiting disease. Th1 cytokines are produced during early stage of the infection while Th2 cytokines are produced during later stages. Balance between Th1 and Th2 cytokines plays an important role in regulating Mycobacterium tuberculosis infection. Components of the Mycobacterium tuberculosis cell wall stimulate production of IL-10 by macrophages, but with a progression of inflammation, $T$ cells become a major source of IL-10 production.

Studies have shown that IL-10 is associated with progression of disease caused by Mycobacterium tuberculosis $(47,48)$. Increased IL-10 down-regulates

TABLE 5. Association of IL-10 polymorphism and haplotype with rheumatoid arthritis.

\begin{tabular}{cccc}
\hline Polymorphism / haplotype & $\begin{array}{c}\text { Frequency of } \\
\text { polymorphism / haplotype } \\
\text { in cases compared to } \\
\text { controls }\end{array}$ & Population & Reference \\
\hline -1082AA & $\downarrow$ & Spanish & de Paz et al. (42); 2010. \\
$-1082 \mathrm{GG}$ & $\downarrow$ & Polish & Paradowska-Gorycka et al. (43); 2010. \\
- -1082GA & $\uparrow$ & Polish & Paradowska-Gorycka et al. (43); 2010. \\
-592CA & $\uparrow$ & Polish & Paradowska-Gorycka et al. (43); 2010. \\
-592AA & $\uparrow$ & Polish & Paradowska-Gorycka et al. (43); 2010. \\
-592A & $\uparrow$ & Chinese & Ying et al. (46); 2011. \\
& $\uparrow$ & Polish & Paradowska-Gorycka et al. (43); 2010. \\
\hline
\end{tabular}

\footnotetext{
$\uparrow$ - increased frequency of polymorphism / haplotype in cases compared to controls.

$\downarrow$ - decreased frequency of polymorphism / haplotype in cases compared to controls.
} 
TABLE 6. Association of IL-10 polymorphism and haplotype with tuberculosis.

\begin{tabular}{cccc}
\hline & $\begin{array}{c}\text { Frequency of } \\
\text { Polymorphism / haplotype } \\
\text { polymorphism / haplotype } \\
\text { in cases compared to } \\
\text { controls }\end{array}$ & Population & Reference \\
\hline$-819 C$ & $\uparrow$ & Asian & Liang et al. (57); 2014. \\
-592CC & $\uparrow$ & Asian & Liang et al. (57); 2014. \\
-1082AA & $\downarrow$ & meta-analysis & Zhang et al. (54); 2011. \\
-1082GG & $\uparrow$ & Pakistani & Ansari et al. (55); 2009. \\
\hline
\end{tabular}

$\uparrow$ - increased frequency of polymorphism / haplotype in cases compared to controls.

$\downarrow$ - decreased frequency of polymorphism / haplotype in cases compared to controls.

secretion of important anti-mycobacterial molecules: TNF-a and nitric oxide, expression of costimulatory molecules and major histocompatibility complex (MHC) class II by macrophages and IFN- $\gamma$ production by $T$ cells $(49,50)$. These findings suggest that IL-10 is associated with promotion of pathological processes and Mycobacterium tuberculosis survival inside host macrophages during infection.

High concentration of IL-10 has been found in sera (51) and lungs (52) of patients with tuberculosis. Neutralization of endogenous IL-10 enhanced T cell IFN- $\gamma$ production, expression of costimulatory molecules and accelerated the clearance of mycobacteria. Association of IL-10 polymorphism with tuberculosis is shown in Table 6. There were no statistically significant differences observed between patients with TBC and controls for the frequency of IL-10 -1082 alleles or genotypes ( $P$ > $0.05)$; however, a statistically significant difference in the frequency of IL-10 -1082GG genotype was found between patients with pulmonary and extrapulmonary TBC $(P=0.003)$ (53). Genotype -1082AA (low IL-10 producer) is associated with resistance to pulmonary tuberculosis (54) while genotype -1082GG (high IL-10 producer) is associated with the risk of developing tuberculosis $(55,56)$. Meta-analysis that included 31 studies with 6559 cases and 7768 controls showed that three polymorphisms (-1082G/A, $-819 \mathrm{~T} / \mathrm{C}$ and $-592 \mathrm{~A} / \mathrm{C})$ in the IL-10 gene were not associated with the risk of TBC in general population, but in the subgroup analy- sis by ethnicity, IL-10 -1082AA and -1082AG genotypes were associated with the TBC risk in Europeans and Americans, while IL-10 -819C allele and $-592 \mathrm{CC}$ and -592AC genotypes were significantly associated with the TBC risk in Asians (57).

\section{IL-10 in melanoma and other malignancies}

Cancer is a multifactorial disease, resulting from complex interactions between genetic and environmental factors. Cytokines also have an important role in cancer. They can either inhibit tumour development and progression if they are released in response to inflammation or they can induce tumour invasion and metastasis if they inhibit apoptosis or promote growth. Since IL-10 has pleiotropic effects, its role and polymorphisms have been widely studied in different types of cancer. The role of IL-10 in cancer is best described in development and progression of melanomas.

Kriiger-Krasagakes et al. (58) investigated the expression of IL-10 mRNA in tissue specimens of primary malignant melanomas and melanoma metastases as compared with normal skin. Their results showed that IL-10 mRNA was found in primary tumours tissues and metastases but not in normal skin. However, they could not distinguish which cells in the tumour tissue are producing IL10 mRNA, infiltrating cells ( $B$ cells, $T$ cells and monocytes) or melanoma cells. Sato et al. (59) showed by cell separation experiments and intracellular staining that the melanoma cells themselves are the major source of IL-10. They did not 
exclude the possibility that tumour-associated leukocytes also produce IL-10 but suggested that their contribution would be minor.

IL-10 production by tumour cells increases as primary melanomas progress from melanoma in situ to invasive melanoma and metastatic melanoma (60). It is believed that IL-10 may have different roles during tumour development and progression. Melanoma cells express IL-10R (61) so IL-10 acts as an autocrine growth factor. In the presence of IL-10 the proliferation of melanoma cells was increased, the cells grew faster and the survival period of cells was prolonged. Melanoma cells also express gangliosides such as GD3 and GM3, which are important for tumour growth and metastasis. CD1 molecules, which are expressed by APC such as dendritic cells, recognize those gangliosides and destruct the cells. However, melanoma cells, by secreting IL-10, down-regulate CD1 molecules on infiltrating dendritic cells and escape the immune response directed against the tumour (62). IL-10 also down-regulates human leukocyte antigen (HLA) class I, HLA class II and intercellular ad- hesion molecule 1 (ICAM-1) on human melanoma cells and therefore also the T-cell response. Apart from this immune-evading mechanism, it was demonstrated that IL-10 shows an anti-tumour effect via inhibition of angiogenesis (63), so its function in melanomas remains complex and still unclear. Presence of low producing ATA haplotype at position $-1082,-819,-592$ is associated with the susceptibility to melanoma (64).

Association of IL-10 polymorphisms and other malignancies are shown in Table 7. IL-10 -1082G allele is associated with numerous other malignancies: non-small cell lung cancer (NSCLC) (65), diffuse large B-cell lymphoma (DLBCL) $(66,67)$, cervical (68) and oral (69) cancer. In Chinese population alleles $-819 \mathrm{C}$ and $-592 \mathrm{C}$ were significantly associated with the occurrence of NSCLC (65). The frequencies of -819T and -592A alleles were lower in French patients ( $\mathrm{N}=199)$ with DLBCL compared to controls $(\mathrm{N}=112)(66)$. Yu et al. (70) in a meta-analysis, based on 73 studies that included 15942 cases and 22336 controls, found that -819 CT genotype is a risk factor for cervical and ovarian cancer. Prostate

TABLE 7. Association of IL-10 polymorphism and haplotype with other malignancies.

\begin{tabular}{|c|c|c|c|c|}
\hline $\begin{array}{l}\text { Polymorphism } \\
\text { / haplotype }\end{array}$ & $\begin{array}{c}\text { Frequency of } \\
\text { polymorphism / haplotype } \\
\text { in cases compared to } \\
\text { controls }\end{array}$ & Population & Malignancy & Reference \\
\hline \multirow{5}{*}{$-1082 G$} & \multirow{5}{*}{$\uparrow$} & Chinese & non-small cell lung cancer & Shih et al. (65); 2005. \\
\hline & & French & diffuse large B-cell lymphoma & Lech-Maranda et al. (66); 2004. \\
\hline & & Japanese & cervical cancer & Matsumoto et al. (68); 2010. \\
\hline & & Greek & oral cancer & Vairaktaris et al. (69); 2008. \\
\hline & & Meta-analysis & diffuse large B-cell lymphoma & Cao et al. (67); 2013. \\
\hline$-819 C$ & $\uparrow$ & Chinese & non-small cell lung cancer & Shih et al. (65); 2005. \\
\hline$-819 T$ & $\downarrow$ & French & diffuse large B-cell lymphoma & Lech-Maranda et al. (66); 2004. \\
\hline$-819 C T$ & $\uparrow$ & Meta-analysis & cervical and ovarian cancer & Yu et al. (70); 2013. \\
\hline \multirow{2}{*}{-819TT } & \multirow{2}{*}{$\uparrow$} & Finnish & prostate cancer & Faupel-Badger et al. (71); 2008. \\
\hline & & Croatian & colon cancer & Cacev et al. (72); 2008. \\
\hline$-592 C$ & $\uparrow$ & Chinese & non-small cell lung cancer & Shih et al. (65); 2005. \\
\hline$-592 A$ & $\downarrow$ & French & diffuse large B-cell lymphoma & Lech-Maranda et al. (66); 2004. \\
\hline \multirow{2}{*}{$-592 A A$} & \multirow{2}{*}{$\uparrow$} & Finnish & prostate cancer & Faupel-Badger et al. (71); 2008. \\
\hline & & Croatian & colon cancer & Cacev et al. (72); 2008. \\
\hline
\end{tabular}

$\uparrow$ - increased frequency of polymorphism / haplotype in cases compared to controls.

$\downarrow$ - decreased frequency of polymorphism / haplotype in cases compared to controls. 
cancer in Finish (71) and colon cancer in Croatian populations (72) are associated with low IL-10 mRNA expression genotypes -819TT and -592AA. No significant differences in allele frequency or genotype distribution were observed for any of the IL-10 SNPs between patients with prostate cancer $(N=262)$ and control subjects $(N=270)$. However, significantly higher frequencies of $-1082 \mathrm{G}(\mathrm{P}$ $=0.005),-819 \mathrm{C}(\mathrm{P}=0.043)$ and $-592 \mathrm{C}(\mathrm{P}=0.043)$ allele and GCC haplotype ( $P=0.008$ ) were observed in early stage patients in comparison to advanced prostate cancer patients (73).

\section{Conclusion}

Production of IL-10 is stimulated by various endogenous and exogenous factors, but certain allelic variants of IL-10 gene are also associated with differences in IL-10 expression. Genetic association studies are performed to determine whether a genetic variant is associated with the disease. IL-10 has been shown to be a candidate gene in the pathophysiologic mechanism of autoimmune diseases, inflammatory diseases and some neoplasms since it regulates both cellular and humoral immunity. Three SNPs $(-1082(\mathrm{G} / \mathrm{A}),-819(\mathrm{C} / \mathrm{T}),-592(\mathrm{C} / \mathrm{A}))$ in the promoter region of the IL10 gene have been shown to alter IL-10 mRNA and protein levels. High expression of allele $-1082 \mathrm{G}$ in patients compared to controls is associated with SLE, CD and neoplasms (non-small cell lung cancer, diffuse large B-

\section{References}

1. Gastl GA, Abrams JS, Nanus DM, Oosterkamp R, Silver J, Liu $F$, et al. Interleukin-10 production by human carcinoma cell lines and its relationship to interleukin-6 expression. Int J Cancer 1993;55:96-101. http://dx.doi.org/10.1002/ ijc.2910550118.

2. Pisa P, Halapi E, Pisa EK, Gerdin E, Hising C, Bucht A, et al. Selective expression of interleukin 10, interferon-gamma and granulocyte-macrophage colony-stimulating factor in ovarian cancer biosies. Proc Nat Acad Sci USA 1992;89:770812. http://dx.doi.org/10.1073/pnas.89.16.7708.

3. Spits $H$, De Waal Malefyt R. Functional characterization of human IL-10. Int Arch Allergy Appl Immunol 1992;99:8-15. http://dx.doi.org/10.1159/000236329. cell lymphoma, cervical and oral cancer) and promotes development of pathological processes in these diseases. Genotype -1082AA is more prevalent in asthma, while in TBC and Crohn's disease genotype -1082GG has higher frequency in cases compared to controls. Genotype -819TT is associated with low level of IL-10 in patients with colon cancer. In the presence of low IL-10 production allele -592A and genotype -592AA in RA, expression of anti-inflammatory cytokine IL-10 is low and insufficient to counterbalance the effect of pro-inflammatory cytokines. In patients with asthma, prostate and colon cancer frequency of low IL-10 production genotype -592AA is higher compared to controls. However, it is necessary to perform additional studies to fully understand the association of IL-10 polymorphisms with disease predisposition and underlying pathological processes.

Both overexpression (SLE, tuberculosis) as well as IL-10 deficiency (inflammatory bowel disease, psoriasis, asthma, rheumatoid arthritis) are likely to have a pathophysiological significance. Therefore, neutralization of the cytokine could be a promising approach to treat diseases from the first group, whereas application of IL-10 itself could be helpful for diseases from the second group. The role of IL10 as a therapeutic agent has been described in other reviews $(74,75,76,77)$.

\section{Potential conflict of interest}

None declared.

4. Eskdale J, Gallagher G. A polymorphic dinucleotide repeat in the human IL-10 promoter. Immunogenetics 1995:42:444-5. http://dx.doi.org/10.1007/BF00179416.

5. Eskdale J, Kube D, Gallagher G. A second polymorphic dinucleotide repeat in the 5 flanking region of the human IL10 gene. Immunogenetics 1996;45:82-3. http://dx.doi. org/10.1007/s002510050174.

6. Eskdale J, Kube D, Tesch H, Gallagher G. Mapping of the human IL10 gene and further characterization of the 5 flanking sequence. Immunogenetics 1997;46:120-8. http:// dx.doi.org/10.1007/s002510050250. 
7. Defrance $T$, Vanbervliet B, Briere $F$, Durand I, Rousset $F$, Banchereau J. Interleukin 10 and transforming growth factor beta cooperate to induce anti- CD40-activated naive human $B$ cells to secrete immunoglobulin $A$. J Exp Med 1992;175:671-82. http://dx.doi.org/10.1084/ jem.175.3.671.

8. Borish L, Aarons A, Rumbyrt J, Cvietusa P, Negri J, Wenzel $S$. Interleukin-10 regulation in normal subjects and patients with asthma. J Allergy Clin Immunol 1996;97:1288-96. http://dx.doi.org/10.1016/S0091-6749(96)70197-5.

9. Rosenwasser LJ, Borish L. Genetics of Atopy and Asthma: The Rationale behind Promoter-based Candidate Gene Studies (IL-4 and IL-10). Am J Respir Crit Care Med 1997;156:152-5. http://dx.doi.org/10.1164/ ajrccm.156.4.12tac-14.

10. Chatterjee R, Batra J, Kumar A, Mabalirajan U, Nahid S, Niphadkar PV, Ghosh B. Interleukin 10 promoter polymorphisms and atopic asthma in North Indians. Clin Exp Allergy 2005;35:914-9. http://dx.doi.org/10.1111/j.13652222.2005.02273.x.

11. Zheng XY, Guan WJ, Mao C, Chen HF, Ding $H$, Zheng JP, et al. Interleukin-10 promoter 1082/-819/-592 polymorphisms are associated with asthma susceptibility in Asians and atopic asthma: a meta-analysis. Lung 2014;192:65-73. http://dx.doi.org/10.1007/s00408-013-9519-8.

12. Nie $W$, Fang $Z$, Li B, Xiu QY. Interleukin-10 promoter polymorphisms and asthma risk: a meta-analysis. Cytokine 2012;60:849-55. http://dx.doi.org/10.1016/j. cyto.2012.08.023.

13. Hyun $M H$, Lee $C H$, Kang MH, Park BK, Lee YH. Interleukin-10 Promoter Gene Polymorphisms and Susceptibility to Asthma: A Meta-Analysis. PLOS ONE 2013;8:e53758. http:// dx.doi.org/10.1371/journal.pone.0053758.

14. Peng H, Wang W, Zhou M, Li R, Pan HF, Ye DQ. Role of interleukin-10 and interleukin-10 receptor in systemic lupus erythematosus. Clin Rheumatol 2013;32:1255-66. http:// dx.doi.org/10.1007/s10067-013-2294-3.

15. Llorente L, Richaud-Patin Y, Wijdenes J, Alcocer-Varela J, Maillot MC, Durand-Gasselin I, et al. Spontaneous production of interleukin-10 by $B$ lymphocytes and monocytes in systemic lupus erythematosus. Eur Cytokine Netw 1993;4:421-7.

16. Rahman A. Meeting report: Cytokines in systemic lupus erythematosus, London, UK. Arthritis Res Ther 2003;5:1604. http://dx.doi.org/10.1186/ar767.

17. Llorente L, Zou W, Levy Y. Role of interleukin 10 in the $B$ lymphocyte hyperactivity and autoantibody production of human systemic lupus erythematosus. J Exp Med 1995;181:839-44. http://dx.doi.org/10.1084/ jem.181.3.839.

18. Arora V, Verma J, Marwah V, Kumar A, Anand D, Das N. Cytokine imbalance in systemic lupus erythematosus: $a$ study on northern Indian subjects. Lupus 2012;21:596-603. http://dx.doi.org/10.1177/0961203311434937.

19. Schotte $H$, Willeke $P$, Becker $H$, Poggemeyer J, Gaubitz $M$, Schmidt $H$, Schlüter B. Association of extended interleukin-10 promoter haplotypes with disease susceptibility and manifestations in German patients with systemic lupus erythematosus. Lupus 2014;23:378-85. http://dx.doi. org/10.1177/0961203314522334.
20. da Silva $H D$, da Silva $A P$, da Silva $H A$, Asano NM, Maia Mde $M$, de Souza PR. Interferon gamma and Interleukin 10 polymorphisms in Brazilian patients with systemic lupus erythematosus. Mol Biol Rep 2014;41:2493-500. http:// dx.doi.org/10.1007/s11033-014-3106-9.

21. Sharif MN, Tassiulas I, Hu Y, Mecklenbrauker I, Tarakhovsky A, Ivashkiv LB. IFN-alpha Priming Results in a Gain of Proinflammatory Function by IL-10: Implications for Systemic Lupus Erythematosus Pathogenesis. J Immunol 2004;172:6476-81. http://dx.doi.org/10.4049/jimmunol.172.10.6476.

22. Rönnelid J, Tejde A, Mathsson L, Nilsson-Ekdahl K, Nilsson $B$. Immune complexes from SLE sera induce IL 10 production from normal peripheral blood mononuclear cells by an FcgRll dependent mechanism: implications for a possible vicious cycle maintaining B cell hyperactivity in SLE. Ann Rheum Dis 2003;62:37-42. http://dx.doi.org/10.1136/ ard.62.1.37.

23. Wang B, Fan YG, Ye DQ. Lack of association between the haplotype GCC/ATA polymorphism in the IL-10 promoter and SLE risk: evidence from a meta-analysis. $Z$ Rheumatol 2013;72:705-8. http://dx.doi.org/10.1007/s00393-013 1158-1.

24. Liu P, Song J, Su H, Li L, Lu N, Yang R, Peng Z. IL-10 Gene Polymorphisms and Susceptibility to Systemic Lupus Erythematosus: A Meta-Analysis. PloS ONE 2013;8:e69547. http://dx.doi.org/10.1371/journal.pone.0069547.

25. Song GG, Choi SJ, Ji JD, Lee YH. Associations between interleukin-10 polymorphisms and susceptibility to systemic lupus erythematosus: a meta-analysis. Hum Immunol 2013;74:364-70. http://dx.doi.org/10.1016/j.humimm.2012.11.020.

26. Zhou $M$, Ding $L$, Peng $H$, Wang $B$, Huang $F, X u W D$, et al. Association of the interleukin-10 gene polymorphism $(-1082 A / G)$ with systemic lupus erythematosus: a meta-analysis. Lupus 2013;22:128-35. http://dx.doi. org/10.1177/0961203312468623.

27. Nath SK, Harley JB, Lee YH. Polymorphisms of complement receptor 1 and interleukin-10 genes and systemic lupus erythematosus: a meta-analysis. Hum Genet 2005;118:225-34. http://dx.doi.org/10.1007/s00439-0050044-6.

28. Asadullah K, Sabat $R$, Friedrich $M$, Volk HD, Sterry W. Interleukin-10: an important immunoregulatory cytokine with major impact on psoriasis. Curr Drug Targets Inflamm Allergy 2004;3:185-92. http://dx.doi. org/10.2174/1568010043343886.

29. Karam RA, Zidan HE, Khater MH. Polymorphisms in the TNF- $a$ and IL-10 gene promoters and risk of psoriasis and correlation with disease severity. Cytokine 2014;66:101-5. http://dx.doi.org/10.1016/j.cyto.2014.01.008.

30. Kingo K, Kõks S, Silm H, Vasar E. IL-10 promoter polymorphisms influence disease severity and course in psoriasis. Genes Immun 2003;4:455-7. http://dx.doi.org/10.1038/ sj.gene.6364004.

31. Lee YH, Choi SJ, Ji JD, Song GG. Associations between interleukin-10 polymorphisms and susceptibility to psoriasis: a meta-analysis. Inflamm Res 2012;61:657-63. http://dx.doi. org/10.1007/s00011-012-0458-2. 
32. Fernández L, Martínez A, Mendoza JL, Urcelay E, Fernández-Arquero $M$, García-Paredes J, et al. Interleukin-10 polymorphisms in IBD Spanish patients. Inflamm Bowel Dis 2005;11:739-43. http://dx.doi.org/10.1097/01. MIB.0000173457.64868.20.

33. Zhu $H$, Lei $X$, Liu $Q$, Wang Y. Interleukin-10-1082A/G polymorphism and inflammatory bowel disease susceptibility: A meta-analysis based on 17,585 subjects. Cytokine 2013;61:146-53. http://dx.doi.org/10.1016/j.cyto. 2012. 09.009

34. Lv H, Jiang Y, Li J, Zhang M, Shang Z, Zheng J, et al. Association between polymorphisms in the promoter region of interleukin-10 and susceptibility to inflammatory bowel disease. Mol Biol Rep 2014;41:1299-310. http://dx.doi. org/10.1007/s11033-013-2975-7.

35. Isomäki P, Luukkainen $R$, Saario R, Toivanen P, Punnonen J. Interleukin-10 functions as an antiinflammatory cytokine in rheumatoid synovium. Arthritis Rheum 1996;39:386-95. http://dx.doi.org/10.1002/art.1780390306.

36. MacDonald KP, Pettit AR, Quinn C, Thomas GJ, Thomas $R$. Resistance of rheumatoid synovial dendritic cells to the immunosuppressive effects of IL-10. J Immunol 1999; 163:5599-607.

37. Antoniv TT, Ivashkiv LN. Dysregulation of Interleukin-10Dependent Gene Expression in Rheumatoid Arthritis Synovial Macrophages. Arthritis Rheum 2006;54:2711-21. http://dx.doi.org/10.1002/art.22055.

38. Lapadula G, lannone F, Dell'Accio F, Covelli M, Pipitone V. Interleukin-10 in rheumatoid arthritis. Clin Exp Rheumatol 1995;13:629-32.

39. Avramescu C, Vere CC, Margaritescu CL, Turculeanu A, Balasoiu M, Rogoz S. Cytokinic panel in rheumatoid arthritis and correlation with histological patterns of synovitis - active type of disease. Rom J Morphol Embryo 2005;46:87-92.

40. Lacki JK, Klama K, Porawska W, Mackiewicz SH, Müller W, Wiktorowicz K. Interleukin 10 inhibits interleukin 6 production and acute phase response in rheumatoid arthritis. Arch Immunol Ther Exp 1995;43:11-4.

41. St Clair EW. Interleukin 10 treatment for rheumatoid arthritis. Ann Rheum Dis 1999;58:99-102. http://dx.doi. org/10.1136/ard.58.2008.i99.

42. de Paz B, Alperi-López M, Ballina-García FJ, Prado C, Mozo L, Gutiérrez C, Suárez A. Interleukin 10 and tumor necrosis factor-alpha genotypes in rheumatoid arthritis - association with clinical response to glucocorticoids. J Rheumatol 2010;37:503-11. http://dx.doi.org/10.3899/jrheum.090566.

43. Paradowska-Gorycka A, Trefler J, Maciejewska-Stelmach J, Lacki JK. Interleukin-10 gene promoter polymorphism in Polish rheumatoid arthritis patients. Int J Immunogenet 2010;37:225-31. http://dx.doi.org/10.1111/j.1744313X.2010.00913.x.

44. Zhang J, Zhang $Y$, Jin J, Li M, Xie K, Wen $C$, et al. The $-1082 A / G$ polymorphism in the Interleukin-10 gene and the risk of rheumatoid arthritis: a meta-analysis. Cytokine 2011;56:351-5. http://dx.doi.org/10.1016/j. cyto.2011.05.022.
45. Lee YH, Bae SC, Choi SJ, Ji JD, Song GG. Associations between interleukin-10 polymorphisms and susceptibility to rheumatoid arthritis: a meta-analysis. Mol Biol Rep 2012;39:81-7. http://dx.doi.org/10.1007/s11033-011-0712-7.

46. Ying $B$, Shi $Y$, Pan $X$, Song $X$, Huang $Z$, Niu Q, et al. Association of polymorphisms in the human IL-10 and IL-18 genes with rheumatoid arthritis. Mol Biol Rep 2011;38:379-85. http://dx.doi.org/10.1007/s11033-010-0119-x.

47. Turner J, Gonzalez-Juarrero M, Ellis DL, Basaraba RJ, Kipnis A, Orme IM, Cooper AM. In vivo IL-10 production reactivates chronic pulmonary tuberculosis in C57BL/6 mice. J Immunol 2002;169:6343-51. http://dx.doi.org/10.4049/ jimmunol.169.11.6343.

48. Wang JY, Chang HC, Liu JL, Shu CC, Lee CH, Wang JT, Lee LN. Expression of toll-like receptor 2 and plasma level of interleukin-10 are associated with outcome in tuberculosis. Eur J Clin Microbiol Infect Dis 2012;31:2327-33. http://dx.doi. org/10.1007/s10096-012-1572-3.

49. Redford PS, Murray PJ, O'Garra A. The role of IL-10 in immune regulation during $M$. tuberculosis infection. Mucosal Immunol 2011;4:261-70. http://dx.doi.org/10.1038/ mi.2011.7.

50. O'Leary S, O'Sullivan MP, Keane J. IL-10 blocks phagosome maturation in mycobacterium tuberculosis-infected human macrophages. Am J Respir Cell Mol Biol 2011;45:17280. http://dx.doi.org/10.1165/rcmb.2010-03190C.

51. Verbon A, Juffermans $N$, Van Deventer SJ, Speelman $P$, Van Deutekom H, Van Der Poll T. Serum concentrations of cytokines in patients with active tuberculosis (TB) and after treatment. Clin Exp Immunol 1999:115:110-3. http://dx.doi. org/10.1046/j.1365-2249.1999.00783.x.

52. Barnes PF, Lu S, Abrams JS, Wang E, Yamamura M, Modlin $R L$. Cytokine production at the site of disease in human tuberculosis. Infect Immun 1993;61:3482-9.

53. Mosaad $Y M$, Soliman $O E$, Tawhid ZE, Sherif DM. Interferon-gamma +874 T/A and Interleukin-10 -1082 A/G Single nucleotide Polymorphism in Egyptian Children with Tuberculosis. Scand J Immunol 2010;72:358-64. http://dx.doi. org/10.1111/j.1365-3083.2010.02426.x.

54. Zhang J, Chen $Y$, Nie XB, Wu WH, Zhang H, Zhang $M$, et al. Interleukin-10 polymorphisms and tuberculosis susceptibility: a meta-analysis. Int J Tuberc Lung Dis 2011;15:594601. http://dx.doi.org/10.5588/ijtld.09.0703.

55. Ansari A, Talat N, Jamil B, Hasan Z, Razzaki T, Dawood $G$, Hussain R. Cytokine Gene Polymorphisms across Tuberculosis Clinical Spectrum in Pakistani Patients. PLoS ONE 2009;4:e4778. http://dx.doi.org/10.1371/journal. pone.0004778.

56. Meenakshi $P$, Ramya S, Shruthi T, Lavanya J, Mohammed $H H$, Mohammed SA, et al. Association of IL-1 $\beta+3954 C / T$ and IL-10-1082 G/A cytokine gene polymorphisms with susceptibility to tuberculosis. Scand J Immunol 2013;78:927. http://dx.doi.org/10.1111/sji.12055.

57. Liang B, Guo Y, Li Y, Kong H. Association between IL-10 gene polymorphisms and susceptibility of tuberculosis: evidence based on a meta-analysis. PLoS One 2014;9:e88448. http:// dx.doi.org/10.1371/journal.pone.0088448. 
58. Kriiger-Krasagakes S, Krasagakis K, Garbe C, Schmitt E, Hiuls C, Blankensteinl T, Diamantstein T. Expression of interleukin 10 in human melanoma. Br J Cancer 1994;70:11825. $h$ ttp://dx.doi.org/10.1038/bjc.1994.469.

59. Sato T, McCue P, Masuoka K, Salwen S, Lattime EC, Mastrangelo $M J$, Berd D. Interleukin 10 production by human melanoma. Clin Cancer Res 1996;2:1383-90.

60. Eijun I, Rong-Rong H, Duan-Ren W, Eberhard P, Wünsch PH, Cochran AJ. IL-10 expression by primary tumor cells correlates with melanoma progression from radial to vertical growth phase and development of metastatic competence. Mod Pathol 2011;24:801-9. http://dx.doi.org/10.1038/ modpathol.2011.5.

61. Yue FY, Dummer $R$, Geertsen $R$, Hofbauer $G$, Laine $E, M a-$ nolio S, Burg G. Interleukin-10 is a growth factor for human melanoma cells and down-regulates HLA class-I, HLA class-II and ICAM-1 molecules. Int J Cancer 1997;71:630-7. http://dx.doi.org/10.1002/(SICI)10970215(19970516)71:4<630::AID-IJC20>3.0.CO;2-E.

62. Gerlini G, Tun-Kyi A, Dudli C, Burg G, Pimpinelli N, Nestle FO. Metastatic Melanoma Secreted IL-10 Down-Regulates CD1 Molecules on Dendritic Cells in Metastatic Tumor Lesions. Am J Pathol 2004;165:1853-63. http://dx.doi.org/10.1016/ S0002-9440(10)63238-5.

63. Howell WM, Turner SJ, Bateman AC, Theaker JM. IL-10 promoter polymorphisms influence tumour development in cutaneous malignant melanoma. Genes Immun 2001;2:25-31. http://dx.doi.org/10.1038/sj.gene.6363726.

64. Vuoristo MS. The polymorphisms of interleukin-10 gene influence the prognosis of patients with advanced melanoma. Cancer Genet Cytogen 2007;176:54-7. http://dx.doi. org/10.1016/j.cancergencyto.2007.03.002.

65. Shih CM, Lee YL, Chiou HL, Hsu WF, Chen WE, Chou $M C$, Lin LY. The involvement of genetic polymorphism of IL-10 promoter in non-small cell lung cancer. Lung Cancer 2005;50:291-7. http://dx.doi.org/10.1016/j. lungcan.2005.07.007.

66. Lech-Maranda E, Baseggio L, Bienvenu J, Charlot C, Berger F, Rigal $D$, et al. Interleukin-10 gene promoter polymorphisms influence the clinical outcome of diffuse large Bcell lymphoma. Blood 2004;103:3529-34. http://dx.doi. org/10.1182/blood-2003-06-1850.
67. Cao HY, Zou P, Zhou H. Genetic association of interleukin-10 promoter polymorphisms and susceptibility to diffuse large B-cell lymphoma: a meta-analysis. Gene 2013;519:288-94. http://dx.doi.org/10.1016/j.gene.2013.01.066.

68. Matsumoto K, Oki A, Satoh T, Okada S, Minaguchi T, Onuki $M$, et al. Interleukin-10 -1082 gene polymorphism and susceptibility to cervical cancer among Japanese women. Jpn J Clin Oncol 2010;40:1113-6. http://dx.doi.org/10.1093/ jjco/hyq094.

69. Vairaktaris E, Yapijakis C, Serefoglou Z, Derka S, Vassiliou S,

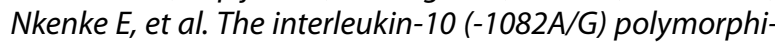
$\mathrm{sm}$ is strongly associated with increased risk for oral squa mous cell carcinoma. Anticancer Res 2008;28:309-14.

70. Yu Z, Liu Q, Huang C, Wu M, Li G. The interleukin 10-819C/ $T$ polymorphism and cancer risk: a HuGE review and meta-analysis of 73 studies including 15,942 cases and 22,336 controls. OMICS 2013;17:200-14. http://dx.doi. org/10.1089/omi.2012.0089.

71. Faupel-Badger JM, Kidd LC, Albanes D, Virtamo J, Woodson K, Tangrea JA. Association of IL-10 polymorphisms with prostate cancer risk and grade of disease. Cancer Causes Control 2008;19:119-24. http://dx.doi.org/10.1007/s10552007-9077-6.

72. Cacev T, Radosevic S, Krizanac S, Kapitanovic S. Influence of interleukin-8 and interleukin-10 on sporadic coIon cancer development and progression. Carcinogenesis 2008;29:1572-80. http://dx.doi.org/10.1093/carcin/bgn 164.

73. Liu J, Song B, Bai X, Liu W, Li Z, Wang J, et al. Association of genetic polymorphisms in the interleukin-10 promoter with risk of prostate cancer in Chinese. BMC Cancer 2010;10:45662. http://dx.doi.org/10.1186/1471-2407-10-456.

74. Asadullah K, Sterry W, Volk HD. Interleukin-10 therapy--review of a new approach. Pharmacol Rev 2003;55:241-69. http://dx.doi.org/10.1124/pr.55.2.4.

75. Li MC, He SH. IL-10 and its related cytokines for treatment of inflammatory bowel disease. World J Gastroenterol 2004; 10:620-5.

76. Walsh GM. Novel therapies for asthma-advances and problems. Curr Pharm Des 2005;11:3027-38. http://dx.doi. org/10.2174/1381612054864984.

77. Clark DN, Markham JL, Sloan CS, Poole BD. Cytokine inhibition as a strategy for treating systemic lupus erythematosus. Clin Immunol 2013;148:335-43. http://dx.doi. org/10.1016/j.clim.2012.11.001. 